\title{
Biotechnological Potential of Endophytic Bacteria to Improve the Micropropagated Seedling of Variety RB92579 Sugarcane (Saccharum officinarum L.)
}

\author{
Maria do Carmo Silva Barreto', Márcia do Vale Barreto Figueiredo ${ }^{2 *}$, Márcia Vanusa da Silva1, \\ Arnóbio Gonçalves de Andrade ${ }^{3}$, José de Paula de Oliveira ${ }^{2}$, Clébia Maria Alves Almeida1, \\ Livia Caroline Alexandre de Araújo', Odemar Vicente dos Reis Junior", \\ Manoel Urbano Ferreira Junior², Antonio Félix da Costa ${ }^{2}$, Vera Lucia de Menezes Lima1 ${ }^{*}$
}

\footnotetext{
${ }^{1}$ Departamento de Bioquímica, Centro de Biociências, Universidade Federal de Pernambuco, Recife, Brazil

${ }^{2}$ Laboratório de Biologia do Solo, Instituto Agronômico de Pernambuco, Recife, Brazil

${ }^{3}$ Departamento de Química, Universidade Federal Rural de Pernambuco, Recife, Brazil

${ }^{4}$ Centro de Tecnologias Estratégicas do Nordeste, Recife, Brazil

Email: *mbarreto@elogica.com.br, ^lima.vera.ufpe@gmail.com
}

How to cite this paper: Barreto, M. do C.S., Figueiredo, M. do V.B., da Silva, M.V., de Andrade, A.G., de Oliveira, J. de P., Almeida, C.M.A., de Araújo, L.C.A., Junior, O.V. dos R., Junior, M.U.F., da Costa, A.F. and Lima, V.L. de M. (2018) Biotechnological Potential of Endophytic Bacteria to Improve the Micropropagated Seedling of Variety RB92579 Sugarcane (Saccharum officinarum L.). Advances in Microbiology, 8, 859-873.

https://doi.org/10.4236/aim.2018.811057

Received: August 27, 2018

Accepted: November 4, 2018

Published: November 7, 2018

Copyright $\odot 2018$ by authors and Scientific Research Publishing Inc. This work is licensed under the Creative Commons Attribution International License (CC BY 4.0).

http://creativecommons.org/licenses/by/4.0/

c) (i) Open Access

\begin{abstract}
Endophytic bacteria may influence agricultural production in several ways, including promoting plant growth. Two experiments were conducted in order to evaluate the combination of endophytic bacteria from the Brazilian Northeast region aims at the commercial introduction of the inoculation of these bacteria in micropropagated sugarcane plants using a temporary immersion bioreactor. One experiment was done in tubes with sterile commercial substrate, and the other was done in pots with soil; both were installed in a greenhouse. A mixed inoculation was performed in six inoculated endophytic diazotrophic bacteria in micropropagated sugarcane plants, variety RB92579. In the experiment with soil, the mixed inoculation significantly increased the shoot dry matter of plants without the addition of nitrogen fertilizer. However, the accumulation of total- $\mathrm{N}$ in the tissues showed no significant differences between treatments with and without nitrogen fertilization. The evaluation of micropropagated seedlings showed no increases in the parameters tested. The results showed that the response of inoculation in temporary immersion bioreactor micropropagation is possible, and that the application of homologous strains may have contributed to a better response by the interaction of endophytic bacteria with sugarcane RB92579. Further studies should be conducted to improve the methodology, which indicates a great potential to optimize this process on a commercial scale.
\end{abstract}




\section{Keywords}

Biological Nitrogen Fixation, Meristem Culture, Diazotrophic Bacteria, Endophytes, Micropropagation

\section{Introduction}

Brazil is the largest producer of sugarcane, with a planted area of approximately 8.6 million hectares, with an estimated production for the 2018/19 season of 62,596 million tons [1]. The production is concentrated in the South-Central and Northeast regions. This culture demands a high amount of nitrogen, the most limiting macronutrient for crop productivity. It is one of the highest costs for farmers. Since fertilizer is not subsidized in Brazil, most commercially used genotypes were chosen aiming to obtain a high productivity with low levels of soil N, favoring; even indirectly, the selection of varieties that are capable of covering part of the need for $\mathrm{N}$ by the association with diazotrophic bacteria [2].

The biological process of converting dinitrogen to ammonia is called nitrogen fixation (BNF), and is performed exclusively by the enzyme nitrogenase, so that it is a great support for the increase in productivity. Moreover, it is also an ecological and more economical alternative [3]. Research has shown that the key to the success of BNF processes lies in the selection of diazotrophic bacteria that can associate more efficiently. Therefore, a more detailed study on the community of diazotrophic bacteria during plant growth cycles is necessary. Studies on inoculation of micropropagated sugarcane plants with a mixture of five strains from different species showed contributions of around 30\% [4]. Nitrogen fixation has a profound agronomic, economic, and ecological impact owing to the fact that the availability of fixed nitrogen represents the factor that most frequently limits agricultural production throughout the world [5].

Micropropagation is a practice widely used in many countries in Europe, Asia, United States and Brazil. This method is based on the production of more uniform and healthy plants and on a much higher growth speed within a limited physical space [6]. However, endophytic microorganisms have been mentioned in several studies as contamination sources to micropropagation. Others consider their presence as a positive factor, arguing that they are able to assist plants, since they live inside their tissues without causing symptoms of their presence, and in the case of in vitro cultivation they can favor osmotic adjustment, production of phytohormones and absorption of nutrients [7] [8]. The reintroduction of diazotrophic endophytic bacteria in micropropagated sugarcane plants has helped studies on the association between plants and diazotrophic bacteria, allowing us to evaluate the potential of BNF and growth promotion [4] [9]. In this context, the present study was performed to evaluate the micropropagated sugarcane seedlings using a temporary immersion bioreactor system aiming the 
commercial introduction of bacterial inoculation as well as the consequent benefit for the culture through a BNF process and/or other mechanisms for promoting plant growth.

\section{Material and Methods}

\subsection{Culture Media}

The culture media used for isolation of bacteria were LGI-P, JNFb, NFb and JMV according to [10]. The medium DYGS [11] was used for the growth of strains and for DNA extraction.

\subsection{Isolation and Quantification of Bacteria}

Triplicate samples of roots and stems of the sugarcane variety RB92579 were obtained from a field in the state of Paraíba $\left(06^{\circ} 57^{\prime} 25.6877^{\prime \prime S}\right.$ latitude and $35^{\circ} 07^{\prime} 06.1412^{\prime W}$ longitude), Brazil. The culms were disinfected with a pre-wash of the surface using soap and water, and then scrubbed with cotton-soaked $70 \%$ alcohol. The roots were disinfected with $70 \%$ alcohol for 30 seconds, then washed with sodium hypochlorite $(2.5 \%)$ for 1 minute under agitation and with sterile water for five times during 5 minutes. After disinfestation, the roots were ground in $90 \mathrm{~mL}$ of a saline solution, thus characterizing a dilution of $10^{-1}$, with three replications [10]. Then, they were diluted serially in $0.1 \mathrm{~mL}$ of suspension and inoculated in vials containing $5 \mathrm{~mL}$ of semisolid free-N, LGI-P, NFb, JNFb and JMV. According to Dobereiner et al. [10], each medium is selective for a particular genus of diazotrophic bacteria: NFb (Azospirillum spp), JNFb (Herbaspirillum spp), LGI-P (Gluconacetobacter diazotrophicus) and JMV (Burkholderia spp). After 72 - $96 \mathrm{~h}$ of incubation, the pots with a white film on the surface were also replicated for a new source medium.

\subsection{DNA Extraction}

DNA bacterial extraction was conducted using phenol-chloroform. Endophytic bacterium isolates were grown in $5 \mathrm{~mL}$ DYGS [11] for $24 \mathrm{~h}$ at $28^{\circ} \mathrm{C}$. A $400 \mu \mathrm{L}$ aliquot of the solution was transferred to a microtube and $400 \mu \mathrm{L}$ saturated phenol solution was added. The mixture was shaken in a vortex apparatus and subjected to centrifugation at $16,000 \mathrm{~g}$ for $5 \mathrm{~min}$. The supernatant (aqueous layer) was transferred to a new microtube and the phenolic step was repeated. After centrifugation the supernatant was again transferred to a new microtube and $400 \mu \mathrm{L}$ chloroform was added. The microtube was shaken in a vortex and centrifuged for $5 \mathrm{~min}$ at $16,000 \mathrm{~g}$. The aqueous layer was transferred to another microtube, to which $1 \mathrm{~mL}$ cold ethanol was added. To complete the process of extracting the DNA, the microtube was centrifuged for $3 \mathrm{~min}$ at $16,000 \mathrm{~g}$, the ethanol discarded, and the tubes incubated at $37^{\circ} \mathrm{C}$ for $30 \mathrm{~min}$ to evaporate residual solvent. The extracted material was resuspended in $15 \mu \mathrm{L}$ Mili-Q sterile water. 


\subsection{Sequencing of Gene $16 \mathrm{~S}$ rDNA and Gyrase $\beta$}

The $16 \mathrm{~S}$ rDNA gene was amplified as per using universal primers fD1

(5'-AGAGTTTGATCCTGGCTCAG-3') e rD1

(5'-AAGGAGGTGATCCAGCC-3') [12]. Gyrase $\beta$ gene was amplified using gyrB3F (5'-TCCGGCGGTCTGCACGGCGT-3') e gyrB14R

(5'-TTGTCCGGGTTGTACTCGTC-3') gene and PCR product for the isolates was sequenced in both directions.

PCR reactions $(25 \mathrm{uL})$ contained $10 \times$ PCR reaction buffer, $10 \mathrm{mM}$ dNTPs, 50 $\mathrm{mM} \mathrm{MgCl} 2,10$ pmol primer, 15 ng DNA and 2.5 units Taq DNA-polimerase (Invitrogen). The temperature profile consisted of $5 \mathrm{~min}$ initial denaturation at $95^{\circ} \mathrm{C}$ followed by 30 cycles of $94^{\circ} \mathrm{C}$ for $45 \mathrm{sec}, 54^{\circ} \mathrm{C}$ for $45 \mathrm{sec}$, and $72^{\circ} \mathrm{C}$ for 2 min followed by a final extension at $72^{\circ} \mathrm{C}$ for $5 \mathrm{~min}$. PCR product was purified using PureLink PCR Purification Kit (Invitrogen) according to the instructions. Sequencing was performed on an ABI PRISM 9700 capillary sequencer using the ABI Prism Big Dye Terminator Cycle sequencing kit (Applied Biosystems).

The 16S rDNA and Gyrase $\beta$ gene sequences were compared with the GenBank database (http://www.ncbi.nlm.nih.gov/) using BLAST. For local alignment, was used to BLASTn tool (NCBI-www.ncbi.nih.gov) and Multiple alignments were performed with CLUSTAL W [13]. A phylogenetic tree was constructed using MEGA 6 (version 6) [14].

\subsection{Micropropagation of Sugarcane}

Endophytic diazotrophic bacteria were used in the mixture to inoculate sugarcane plants (Table 1).

The experiment was conducted at the Northeast Strategic Technologies Center (CETENE), Recife/PE state, Brazil. Micropropagated sugarcane plants, commercial variety RB92579, were used to evaluate the effects of inoculation of diazotrophic bacteria. Micropropagated plants in a Temporary Immersion Bioreactor (TIB) that did not present contamination at the rooting phase received a mixed bacterial inoculum. For the inoculum, bacteria were grown for 48 hours

Table 1. Bacteria used for mixing the inoculant with the isolated plant tissue of sugarcane variety RB 92579.

\begin{tabular}{ccc}
\hline Genus of bacteria & Identification number of each species. & Plant tissue \\
\hline Enterobacter & $1 \mathrm{~b}$ & Culm \\
Enterobacter & 5 & Root \\
Enterobacter & 10 & Root \\
Enterobacter & 25 & Root \\
Gluconacetobacter & 30 & Culm \\
Enterobacter/Pantoea & 22 & Root \\
\hline
\end{tabular}


in a liquid medium under agitation in a Dygs medium [10], at $30^{\circ} \mathrm{C}$. After mixing each inoculum in equal parts, an aliquot of $6.7 \mathrm{~mL}$ of mixed inoculum with an optical density (O.D. $540 \mathrm{~nm}=0.05)$, containing approximately $10^{4}$ cells $/ \mathrm{mL}$, was added to TIB pots with a capacity of $5000 \mathrm{~mL}$, containing $2000 \mathrm{~mL}$ of MS medium modified by [15] in micropropagated seedlings in rooting phase.

Two experiments were conducted at the CETENE greenhouse. One used plastic tubes filled with the sterilized commercial substrate Basaplant and the other used pots $(8 \mathrm{~L})$ with non-sterile forest soil under greenhouse conditions.

In the first experiment, the mixed inoculation was evaluated with the following treatments:

- One level of inoculation: A combination of previously identified diazotrophic bacteria: Enterobacter + Gluconacetobacter diazotrophicus.

- Two levels of nitrogen fertilizer: Recommended dose $\left(80 \mathrm{~kg}\right.$ of $\left.\mathrm{N} \mathrm{ha}^{-1}\right)$, and without nitrogen fertilization.

- One non-inoculated control with nitrogen fertilization, following the recommended dose.

The experimental design was randomized blocks with four replications. The plants were kept in plastic tubes (acclimatized) for 45 days and fertilized with a nutrient solution. The effects of inoculation considering fertilization was evaluated by determining the accumulation of shoot and root dry mass. The plants were taken to the laboratory, the aerial part was cut and measured with a ruler and the constant dry mass of the samples were obtained after drying the plant material at a temperature of about $70^{\circ} \mathrm{C}$ (degrees Celsius) for at least $48 \mathrm{~h}$. After drying, the material was weighed cold.

For the second experiment, the remainder of the seedlings that did not undergo evaluation during the first experiment was transplanted into 8-liter pots containing non-sterile soil. From this soil, several single samples were collected to form a composite sample, which was then analyzed (Table 2), obtaining the fertilization recommendation. The experimental design was randomized blocks with four replications. After 120 days after planting, evaluations of accumulation of root and shoot dry mass and the determination of total nitrogen accumulated in plant tissues were made using the Kjeldahl method [16].

\subsection{Statistical Analysis}

Each variable studied was subjected to analysis of variance (ANOVA), F test, and Tukey's test, at $5 \%$ significance levels using the statistical software ASSISTAT version 7.7 [17].

Table 2. Chemical characteristics of the soil sample used in the conduction of the second experiment (pots).

\begin{tabular}{|c|c|c|c|c|c|c|c|c|c|c|c|c|c|}
\hline \multicolumn{5}{|c|}{$\mathrm{mg} / \mathrm{dm}^{3}$} & \multirow{2}{*}{$\mathrm{pH}$} & \multicolumn{8}{|c|}{$\mathrm{cmol}_{\mathrm{c}} / \mathrm{dm}^{3}$} \\
\hline $\mathrm{Fe}$ & $\mathrm{Cu}$ & $\mathrm{Zn}$ & $\mathrm{Mn}$ & $\mathrm{p}$ & & $\mathrm{K}$ & $\mathrm{Na}$ & $\mathrm{Al}$ & $\mathrm{Ca}$ & $\mathrm{Mg}$ & $\mathrm{H}$ & S.B & CTC \\
\hline 44.20 & 0.60 & 8.30 & 7.10 & 5 & 6.3 & 0.10 & 0.06 & 0.0 & 4.50 & 0.90 & 2.60 & 5.55 & 8.15 \\
\hline
\end{tabular}




\section{Results and Discussion}

\subsection{Isolation of Diazotrophic Bacteria}

Populations of nitrogen-fixing bacteria were higher in samples of roots compared with samples of culms. Previously conducted tests indicated that the bacteria used in this experiment have an ability to fix $\mathrm{N}_{2}$ in vitro, which becomes a potential tool for the production of IAA and for inorganic phosphate solubilization (Figure 1).

\subsection{Molecular Phylogeny of Bacterial Isolates}

The total DNA of the six bacterial isolates was purified and used as a model for PCR (polymerase chain reaction) in order to amplify their 16S rRNA genes. The sequencing of the 16S rRNA gene allows an accurate identification of the genera of endophytic bacteria from various species of plants, including sugarcane, corn, rice and medicinal plants [18] [19] [20]. However, it is necessary to analyze other genes, such as gyrA and $g y r \beta$, to obtain a precise definition of the species and even subspecies [21]. Using a molecular approach, the occurrence of phylogenetic types of organisms and their distribution in natural communities may be studied directly from the environment. Since 1988, when only twelve phyla of bacteria were reported, the number of phyla increased due to cultivation activities, especially by the research on rRNA genes on the environment. Currently, over 70 phyla of bacteria are recorded in public databases [22]. The sequencing of rRNA genes is an efficient method of choice for phylogenetic reconstruction based on the detection of nucleic acid and the quantification of microbial diversity.

Based on the sequence of the 16S rRNA gene, the endophytic bacterial isolates in this study were identified as Enterobacteria, Gluconacetobacter, Rhizobium, Pantoea and non-cultivable bacteria (Figure 2).

The results of phylogenetic analyses allowed grouping the endophytic sugarcane isolates into two groups, with similarities with sequences in the GenBank public database ranging from $99 \%$ to $100 \%$ (Figure 3).

Group I was composed by the isolates 1, 5, 10, 22 and 25, which are related to Pantoea sp., Rhizobium sp., Enterobacter sp., E. asburiae, E. ludwigii and E. cloacae. This result was confirmed by the sequencing of the gene gyr $\beta$, which enabled identifying the isolates at the species level, such as E. cloacae (Table 3).

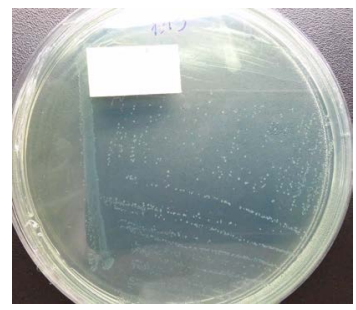

(a)

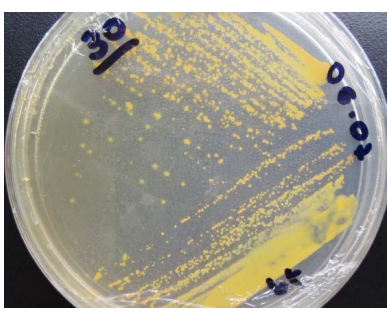

(b)

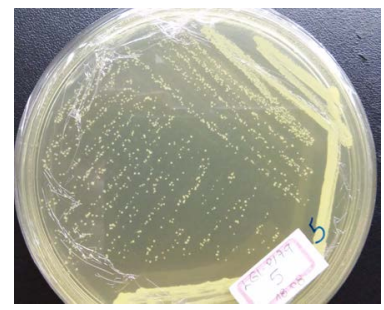

(c)

Figure 1. Colonies of diazotrophic bacteria isolated in different semi-selective medium: $\mathrm{NFb}$ (A), LGI-P (B), JMV (C). 


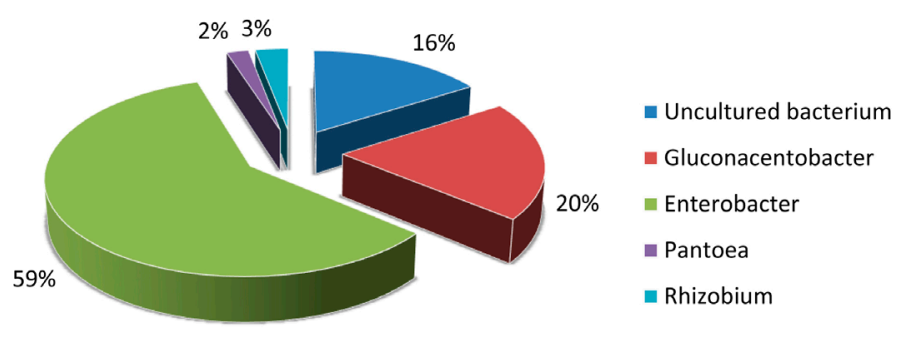

Figure 2. Abundance of each genus identified among endophytic bacterial isolates from RB 92579 sugarcane cultivar.

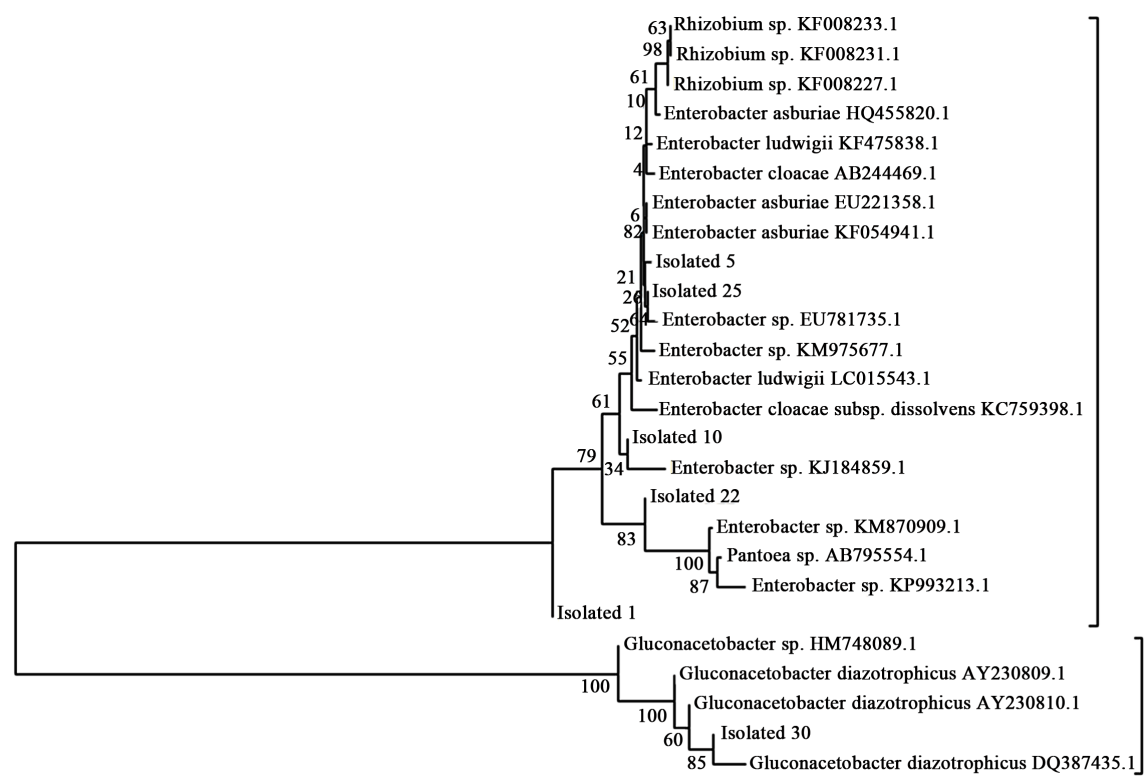

$\longmapsto 0.02$

Figure 3. Phylogenetic tree constructed with sequences of the 16S rRNA regions of endophytic bacteria isolated from sugarcane and sequences from GenBank (indicated by accession number), using the neighbor-joining method and utilizing Tamura-Nei for nucleotides, with the pairwise gap deletion option. Numbers indicate frequency of each branch from bootstrap analyses of 10,000 replicates.

Table 3. Isolated bacterial endophytes identified with relationship to species by sequencing of the gyr $\beta$ gene and the identity percentage found in the National Center for Biotechnology Information database.

\begin{tabular}{cccccc}
\hline Isolates & Species & Query value & E value & Identity & Accession \\
\hline $\mathbf{1}$ & Enterobacter clocae & $100 \%$ & 0.0 & $97 \%$ & $\mathrm{AB} 972391.1$ \\
$\mathbf{5}$ & Enterobacter clocae & $99 \%$ & 0.0 & $94 \%$ & $\mathrm{AB} 084016.1$ \\
$\mathbf{1 0}$ & Enterobacter clocae & $100 \%$ & 0.0 & $98 \%$ & $\mathrm{AB} 972391.1$ \\
$\mathbf{2 2}$ & Enterobacter clocae & $100 \%$ & 0.0 & $97 \%$ & $\mathrm{AB} 972391.1$ \\
$\mathbf{2 5}$ & Enterobacter clocae & $100 \%$ & 0.0 & $94 \%$ & $\mathrm{AB} 084013.1$ \\
\hline
\end{tabular}

Pantoea was found in sugarcane and soybeans [23] is at soja [24]. Studies have shown the potential of Pantoea sp. to induce a systemic resistance and protection against pathogenic microorganisms. Additionally, these bacteria may in- 
duce the growth of plants, increasing the supply of nitrogen in non-symbiotic associations, solubilizing phosphorus and stimulating the production of phytochromes [25].

Although Rhizobia infect naturally legumes as host plants, some strains may form symbiotic relations with non-legume species. Besides fixing $\mathrm{N}_{2}$, they are also capable of contributing to the promotion of growth of these species.

Group II included the isolated 30, which is related to Gluconacetobacter diazotrophicus. G. diazotrophicus is considered the main diazotrophic endophyte in sugarcane and has been isolated from leaves, stems and roots of sugarcane plants and other economically important grasses [23]. Several studies have shown that such endophytes colonize their hosts in vast numbers and cause an increase in production [26] [27]. The possibility of replacing fertilized nitrogen for biological nitrogen fixation is a very important economic and environmental factor [28].

The results obtained in this study are essential to provide the necessary knowledge on the analysis of endophytic bacteria in micropropagated sugarcane plants and to indicate the potential for future applications of endophytes that promote plant growth.

In addition to the common ability to fix $\mathrm{N}_{2}$, associative and endophytic bacteria are genetically diverse. They were identified among various genera: alpha, beta and gamma-proteobacteria, including Azospirillum, Azorhizobium, Azoarcus, Burkholderia, Citrobacter, Enterobacter, Gluconacetobacter, Herbaspirillum, Klebsiella, Pseudomonas and Rhizobium [23] [29].

\subsection{Evaluation of Micropropagated Sugarcane Seedlings}

The results of this experiment showed no significant statistical differences by Tukey test $(p<0.05)$ among treatments inoculated with the mixture of diazotrophic bacteria (with and without nitrogen fertilization) and the control. There was a tendency for increase for the control treatment at this micropropagated phase (Table 4).

Table 4. Effect of inoculation of bacteria from micropropagated sugarcane plants (RB 92579) at the $45^{\text {th }}$ day.

\begin{tabular}{cccc}
\hline Treatment & Height $(\mathrm{cm})$ & RDM $(\mathrm{g})$ & SDM $(\mathrm{g})$ \\
\hline $\begin{array}{c}\text { Control-Nitrogen } \\
\text { Fertilization } \\
\text { Inoculant-Nitrogen } \\
\text { Fertilization } \\
\begin{array}{c}\text { Inoculant-Fertilization } \\
\text { without Nitrogen }\end{array}\end{array}$ & $70.05 \mathrm{a}$ & $0.16 \mathrm{a}$ & $0.54 \mathrm{a}$ \\
$\mathrm{M} \pm$ SD & $64.45 \mathrm{ab}$ & $0.09 \mathrm{~b}$ & $0.37 \mathrm{~b}$ \\
$\mathrm{CV} \%$ & $65.45 \pm 5.92$ & $0.12 \pm 0.05$ & $0.42 \mathrm{~b}$ \\
\hline
\end{tabular}

$\mathrm{RDM}=$ root dry matter; SDM = shoot dry matter. Means followed by the same letters do not differ by Tukey test $(\mathrm{p} \leq 0.05) . \mathrm{M} \pm \mathrm{SD}=$ mean \pm standard deviation. 
Results similar to those obtained in this study were found by [9] upon analyzing the effect of inoculation by determining the accumulation of root and shoot dry mass of sugarcane seedlings, variety SP701143, at the $65^{\text {th }}$ day. In this study, no statistically significant differences were observed among treatments inoculated with 44 strains of diazotrophic bacteria and the non-inoculated control, suggesting that at this stage the plant does not respond adequately to inoculation.

\subsection{Evaluation of Sugarcane in Pots}

The height of plants in pots showed no significant differences by Tukey test $(\mathrm{p}<$ 0.05) among treatments inoculated with the mixture of diazotrophic bacteria (with and without nitrogen fertilization) and the control. The addition of nitrogen fertilizer to the inoculated treatment resulted in a slight decrease in RDM (14.14 g). It did not differ statistically from the control treatment with the addition of nitrogen fertilizer $(16.38 \mathrm{~g})$, evidencing that $\mathrm{N}$ is a limiting factor in this experiment (Table 5). However, the inoculation without nitrogen fertilizer promoted a greater accumulation of root dry matter compared to the control treatment.

The evaluation of the SDM accumulation showed that the mixed inoculation promoted a positive effect on plant development without the addition of nitrogen fertilizer (41.7 g), differing from the other treatments (Table 4).

The results suggest that the inoculation used with the commercial variety RB92579 affected the interaction with inoculated bacteria. A better understanding of the plant-bacteria interaction, the selection of diazotrophic endophyte strains and the variety of cane needs to be further studied aiming a maximum benefit of BNF.

Microbial inoculants are an alternative method to increase crop productivity and may reduce the use of chemical fertilizers, which is one of the agricultural practices that affect the environment [30]. The positive effects of inoculating some bacteria during plant growth may be associated to the BNF process and the synthesis of growth hormones produced by bacteria. Among the effects associated

Table 5. Effect of inoculation of bacteria from micropropagated sugarcane plants (RB 92579 ) in pots (at the $120^{\text {th }}$ day).

\begin{tabular}{ccccc}
\hline Treatment & $\begin{array}{c}\text { Height } \\
(\mathrm{cm})\end{array}$ & $\begin{array}{c}\text { RDM } \\
(\mathrm{g})\end{array}$ & $\begin{array}{c}\text { SDM } \\
(\mathrm{g})\end{array}$ & $\begin{array}{c}\text { Leaf } \\
\mathrm{N}\left(\mathrm{g} / \mathrm{Kg} \mathrm{dry} \mathrm{wt}^{-1}\right)\end{array}$ \\
\hline Control-Nitrogen Fertilization & $1.76 \mathrm{a}$ & $16.38 \mathrm{ab}$ & $35.28 \mathrm{~b}$ & $10.39 \mathrm{a}$ \\
Inoculant-Nitrogen Fertilization & $1.76 \mathrm{a}$ & $14.14 \mathrm{~b}$ & $31.71 \mathrm{~b}$ & $9.90 \mathrm{a}$ \\
Inoculant-Fertilization without Nitrogen & $1.82 \mathrm{a}$ & $17.77 \mathrm{a}$ & $41.70 \mathrm{a}$ & $10.08 \mathrm{a}$ \\
$\mathrm{M} \pm \mathrm{SD}$ & $1.78 \pm 0.10$ & $16.09 \pm 3.14$ & $36.23 \pm 5.63$ & $10.98 \pm 2.68$ \\
$\mathrm{CV} \%$ & 7.73 & 25.57 & 20.35 & 17.81 \\
\hline
\end{tabular}

$\mathrm{RDM}=$ root dry matter; SDM = shoot dry matter. Means followed by the same letters do not differ by Tukey test $(\mathrm{p} \leq 0.05) . \mathrm{M} \pm \mathrm{SD}=$ mean \pm standard deviation. 
with this synthesis of hormones, the growth of lateral and adventitious roots, the stimulus to cell division and the elongation of roots and stems are mentioned [31]. This may explain the accumulation of root dry matter.

Similar results were observed by some authors. Lin et al. [32], upon inoculating two strains of Enterobacter spp., observed that both strains increased the biomass content and the nitrogen of micropropagated sugarcane seedlings grown with a nitrogen fertilizer equivalent to $180 \mathrm{~kg}$ of urea $\mathrm{ha}^{-1}$, a recommended nitrogen fertilization dose for the cultivation of the sugarcane ROC22 at the seedling stage. [4], upon inoculating in micropropagated sugarcane plants different species of diazotrophic bacteria, isolated and in mixtures, observed that Herbaspirillum sp., A. amazonense and a combination of five strains of different bacteria showed a significant increase in the accumulation of fresh mass in the culms of plants, evidencing a $30 \%$ contribution of BNF. However, the individual inoculation of $G$. diazotrophicus promoted a negative effect on the accumulation of fresh mass of culms compared to the non-inoculated control. The results presented by [9] showed that the inoculation response in micropropagated SP 701143 seedlings at the rooting stage showed variations that may have been dependent on several factors, including plant genotype and the environment. In this study, the inoculation with the strains PAL3 and CBAmC caused a significant increase in the accumulation of culm dry matter compared to the non-inoculated control treatment. However, the accumulation of $\mathrm{N}$ in plant tissues grown in pots after 180 days of growth showed that plants inoculated with a mixture of the strains PAL5 and HCC103 and the individual strains HRC54, Z94 and CBAmC showed a higher nitrogen content in the tissues. [33], studying potted micropropagated seedlings, observed that the total biomass increased due to inoculation with one strain or a combination of strains without nitrogen fertilization. [34] inoculated a mixture of diazotrophic bacteria and mycorrhizal fungi in micropropagated sugarcane plants and obtained an effect equivalent to half the recommended dose of nitrogen fertilizers for potted plants. [4] demonstrated that the combined inoculation of associative and endophytic bacteria promotes a synergistic effect compared to the individual inoculation of bacteria in micropropagated sugarcane plants. Increases of $30 \%$ in the accumulation of $\mathrm{N}$ in plants via BNF were observed for these plants.

\subsection{Effects on Growth}

The contribution of endophytic bacteria for the nutrition of legume plants by BNF is well known. Among non-legume species, BNF is still subject of much discussion. The contributions observed are varied and depend on specific interactions among bacterial and plant genotypes [35].

The inoculation of micropropagated sugarcane plants has already been performed and resulted in interesting effects on the outcome of plants. Preliminary inoculation experiments with $G$. diazotrophicus in micropropagated sugarcane plants showed increases of up to $28 \%$ in shoot fresh matter. Promising results were also obtained when micropropagated sugarcane plants were inoculated 
with the strain PAL-5 associated with small doses of nitrogen, as shown by [36].

When the colonization of the plant is established, one result arising from the association is the promotion of plant growth by direct and indirect mechanisms. In addition to fixing $\mathrm{N}$, endophytic diazotrophic bacteria produce plant growth hormones such as auxin and gibberellic acid [37], Improvements in nutrient absorption are also reported [38].

Several experiments demonstrated that endophytic bacteria may indirectly benefit the development of the plant, increasing the plant's tolerance to biotic and abiotic stresses [39] [40] [41]. Beneficial results from such associations in sugarcane plants include a significant increase in plant height and biomass, root length and production of dry matter [42] [43].

Current evidence indicates that the BNF process performed by diazotrophic bacteria may contribute up to $60 \%$ to the sugarcane's $\mathrm{N}$ uptake [2], and that it depends on the plant genotype and on its interaction with various associative bacteria genera [44].

Quantitative analyses of BNF and the promotion of plant growth evidenced that plant and bacterial genotypes are important factors to the control of association efficiency [45]. In this context, the determination of the best combination between diazotrophic bacteria and plant varieties to obtain the maximum benefit of such association in agriculture is a challenge in this area.

\section{Conclusion}

This study showed that inoculation using a temporary immersion bioreactor is possible. This is the first inoculation report for seedlings using this system. The use of homologous strains may also have contributed to the benefit of the interaction with the plant (sugarcane variety RB92579). The results suggest a high response potential to inoculation and optimization of the process on a commercial scale.

\section{Acknowledgements}

Funding: This work was supported by the Conselho Nacional de Desenvolvimento Científico e Tecnológico (CNPq grant number 310030/2015-3), and MCSB obtained a scholarship from Coordenação de Aperfeiçoamento de Pessoal de Nível Superior (CAPES).

\section{Conflicts of Interest}

The authors declare no conflicts of interest regarding the publication of this paper.

\section{References}

[1] Compainha Nacional de Abastecimento-CONAB (2018) Acompanhamento safra brasileira de cana. v 5, Safra 2018/2019, n. 1, Primeiro levantamento, Brasília. https://www.conab.gov.br/info-agro/safras/cana 
[2] Schultz, N., Pereira, W., Reis, V.M. and Urquiaga, S.S. (2016) Produtividade e diluição isotópica de ${ }^{15} \mathrm{~N}$ em Cana-De-Açúcar inoculada com bactérias diazotróficas. Pesquisa Agropecuária Brasileira, 51, 1594-1601. https://doi.org/10.1590/s0100-204x2016000900059

[3] Spatzal, T. (2015) The Center of Biological Nitrogen Fixation: FeMo-Cofactor. Zeitschrift für anorganische und allgemeine Chemie, 641, 10-17. https://doi.org/10.1002/zaac.201400161

[4] Oliveira, A.L.M., Urquiaga, S., Dobereiner, J. and Baldani, J.I. (2002) The Effect of Inoculating Endophitic $\mathrm{N}_{2}$-Fixing Bacteria on Micropropagated Sugarcane Plants. Plant and Soil, 242, 205-215. https://doi.org/10.1023/A:1016249704336

[5] Hoffman, B.M., Lukoyanov, D., Yang, Z., Dean, D.R. and Seefeldt, L.C. (2014) Mechanism of Nitrogen Fixation by Nitrogenase: The Next Stage. Chemical Reviews, 114, 4041-4062. https://doi.org/10.1021/cr400641x

[6] Baldotto, L.E.B., Baldotto, M.A., Canellas, L.P., Bressan-Smith, R. and Olivares, F.L. (2010) Growth Promotion of Pineapple "VitóriA" by Humic Acids and Burkholderia spp. during Acclimatization. Revista Brasileira de Ciência do Solo, 34, 1593-1600. https://doi.org/10.1590/S0100-06832010000500012

[7] Almeida, C.V., Andreote, F.D., Yara, R., Tanaka, F.A.O., Azevedo, J.L. and Almeida, M. (2009) Bacteriosomes in Axenic Plants: Endophytes as Stable Endosymbionts. World Journal Microbiology and Biotechnology, 25, 1757-1764. https://doi.org/10.1007/s11274-009-0073-8

[8] Abreu-Tarazi, M.F., Navarrete, A.A., Andreote, F.D., Almeida, C.V., Tsai, S.M. and Almeida, M. (2010) Endophytic Bacteria in Long-Term in Vitro Cultivated "Axenic” Pineapple Microplants Revealed by PCR-DGGE. World Journal of Microbiology and Biotechnology, 26, 555-560. https://doi.org/10.1007/s11274-009-0191-3

[9] Canuto, E.L., Salles, J.F., Oliveira, A.L.M., Perin, L., Reis, V.M. and Baldani, J.I. (2003) Resposta de plantas micropropagadas de Cana-De-Açúcar à inoculação de bactérias diazotróficas endofíticas. Agronomia, 37, 67-72.

[10] Döbereiner, J., Baldani, V.L.D. and Baldani, J.I. (1995) Como isolar e identificar bactérias diazotróficas em plantas não leguminosas. EMBRAPA-SPI, Brasília.

[11] Rodrigues Neto, J., Malavolta Júnior, V.A. and Victor, O. (1986) Meio simples para isolamento e cultivo de Xanthomonas campestris pv. citri tipo B. Summa Phytopathologica, 12, 16.

[12] Weisburg, W.G., Barns, S.M., Pelletier, D.A. and Gene-Trak, D.J.L. (1991) 16S Ribosomal DNA Amplification for Phylogenetic Study. Dournal of Bacteriology, 173, 697-703. https://doi.org/10.1128/jb.173.2.697-703.1991

[13] Thompson, J.D., Gibson, T.J., Plewniak, F., Jeanmougin, F. and Higgins, D.G. (1997) The CLUSTAL_X Windows Interface: Flexible Strategies for Multiple Sequence Alignment Aided by Quality Tools. Nucleic Acids Research, 24, 4876-4882. https://doi.org/10.1093/nar/25.24.4876

[14] Tamura, K., Stecher, G., Peterson, D., Filipski, A. and Kumar, S. (2013) MEGA6: Molecular Evolutionary Genetics Analysis Version 6.0. Molecular Biology Evolution, 30, 2725-2729. https://doi.org/10.1093/molbev/mst197

[15] Reis, V.M., Olivares, F.L., Oliveira, A.L.M., Reis Junior, F.B., Baldani, J.I. and Dobereiner, J. (1999) Technical Approaches to Inoculate Micropropagated Sugar Cane Plants Were Acetobacter diazotrophicus. Plant and Soil, 206, 205-211. https://doi.org/10.1023/A:1004436611397

[16] Alves, B.J.R., Santos, J.C.F., Urquiarga, S. and Boddey, R.M. (1994) Métodos de determinação do nitrogênio em solo e planta. In: Araújo, R.S. and Hungria, M., 
Eds., Manual de métodos empregados em estudos de microbiologia agrícola, EMBRPA-CNPAF, Documentos 46, Brasília, 449-467.

[17] Silva, F.A.S. and Azevedo, C.A.V. (2016) The Assistant Software Version 7.7 and Its Use in the Analysis of Experimental Data. African Journal Agricultural Research, 11, 3733-3740. https://doi.org/10.5897/AJAR2016.11522

[18] Ratón, T.M.O., Yano, R., Gámez, O.R., Floh, E.I.S., Díaz, M.J.S. and Barbosa, H.R. (2012) Isolation and Characterisation of Aerobic Endospore Forming Bacilli from Sugarcane Rhizosphere for the Selection of Strains with Agriculture Potentialities. World Journal Microbiology and Biotechnology, 28, 1593-1603. https://doi.org/10.1007/s11274-011-0965-2

[19] Szilagyi-Zecchin, V.J., Ikeda, A.C., Hungria, M., Adamoski, D., Kava-Cordeiro, V., Glienke, C. and Galli-Terasawa, L.V. (2014) Identification and Characterization of Endophytic Bacteria from Corn (Zea mays L.) Roots with Biotechnological Potential in Agriculture. AMB Express, 4, 1-9. https://doi.org/10.1186/s13568-014-0026-y

[20] Rhoden, S.A., Garcia, A., Santos e Silva, M.C., Azevedo, J.L. and Pamphile, J.A. (2015) Phylogenetic Analysis of Endophytic Bacterial Isolates from Leaves of the Medicinal Plant Trichilia elegans A. Juss. (Meliaceae). Genetics and Molecular Research, 14, 1515-1525. https://doi.org/10.4238/2015.February.20.7

[21] Hurtle, W., Bode, E., Kulesh, D.A., Kaplan, R.S., Garrison, J., Bridge, D., House, M., Frye, M.S., Loveless, B. and Norwood, D. (2004) Detection of the Bacillus anthracis gyrA Gene by Using a Minor Groove Binder Probe. Journal of Clinical Microbiology, 42, 179-185. https://doi.org/10.1128/JCM.42.1.179-185.2004

[22] Youssef, N.H., Couger, M.B., Mccully, A.L., Criado, A.E.G. and Elshahed, M.S. (2015) Assessing the Global Phylum Level Diversity within the Bacterial Domain: A Review. Journal of Advanced Research, 6, 269-282. https://doi.org/10.1016/j.jare.2014.10.005

[23] Magnani, G.S., Didonet, C.M., Cruz, L.M., Picheth, C.F., Pedrosa, F.O. and Souza, E.M. (2010) Diversity of Endophytic Bacteria in Brazilian Sugarcane. Genetic and Molecular Research, 9, 250-258. https://doi.org/10.4238/vol9-1gmr703

[24] Kuklinsky-Sobral, J., Araújo, W.L., Mendes, R., Geraldi, I.O., Pizzirani-Kleiner, A.P. and Azevedo, J.L. (2004) Isolation and Characterization of Soybean-Associated Bacteria and Their Potential for Plant Growth Promotion. Environmental Microbiology, 12, 1244-1251. https://doi.org/10.1111/j.1462-2920.2004.00658.x

[25] Quecine, M.C., Araújo, W.L., Rossetto, P.B., Ferreira, A., Tsui, S., Lacava, P.T., Mondin, M., Azevedo, J.L. and Pizzirani-Kleinera, A.A. (2012) Sugarcane Growth Promotion by the Endophytic Bacterium Pantoea agglomerans 33.1. Applied and Environmental Microbiology, 78, 7511-7518. https://doi.org/10.1128/AEM.00836-12

[26] Rashid, S., Charles, T.C. and Glick, B.R. (2012) Isolation and Characterization of New Plant Growth-Promoting Bacterial Endophytes. Applied Soil Ecology, 61, 217-224. https://doi.org/10.1016/j.apsoil.2011.09.011

[27] Santoyo, G., Moreno-Hagelsieb, G., Orozco-Mosqueda, M.C. and Glick, B.R. (2016) Plant Growth-Promoting Bacterial Endophytes. Microbiological Research, 183, 92-99. https://doi.org/10.1016/j.micres.2015.11.008

[28] Jha, P.N., Gupta, G., Jha, P. and Mehrotra, R. (2013) Association of Rhizospheric/Endophytic Bacteria with Plants: A Potential Gateway to Sustainable Agriculture. Greener Journal of Agricultural Sciences, 3, 73-84.

[29] Santi, C., Bogusz, D. and Franche, C. (2013) Biological Nitrogen Fixation in Nonlegume Plants. Annals of Botany, 111, 743-767. https://doi.org/10.1093/aob/mct048 
[30] Ambrosini, A., Souza, R. and Passaglia, L.M.P. (2016) Ecological Role of Bacterial Inoculants and Their Potential Impact on Soil Microbial Diversity. Plant and Soil, 400, 193-207. https://doi.org/10.1007/s11104-015-2727-7

[31] Teale, W., Paponov, I. and Palme, K. (2006) Auxin in Action: Signalling, Transport and the Control of Plant Growth and Development. Nature Reviews Molecular Cell Biology, 7, 847-859. https://doi.org/10.1038/nrm2020

[32] Lin, L., Li, Z., Hu, C., Zhang, X., Chang, S., Yang, L., Li, Y. and An, Q. (2012) Plant Growth-Promoting Nitrogen-Fixing Enterobacteria Are in Association with Sugarcane Plants Growing in Guangxi, China. Microbes and Environments, 27, 391-398. https://doi.org/10.1264/jsme2.ME11275

[33] Govindarajan, M., Balandreau, J., Muthukumarasamy, R., Revathi, G. and Lakshminarasimhan, C. (2006) Improved Yield of Micropropagated Sugarcane Following Inoculation by Endophytic Burkholderia vietnamiensis. Plant and Soil, 280, 239-252. https://doi.org/10.1007/s11104-005-3223-2

[34] Muthukumarasamy, R.R.G. and Lakshminarasimhan, C. (1999) Diazotrophic Bacterial Association in Sugarcane Cultivation in South India. Tropical Agriculture, 76, 171-178.

[35] Chaves, V.A., Santos, S.G., Schultz, N., Pereira, W., Souza, J.S., Monteiro, R.C. and Reis, V.M. (2015) Desenvolvimento inicial de duas variedades de cana-de-açúcar inoculadas com bactérias diazotróficas. Revista Brasileira Ciência do Solo, 39, 1595-1602. https://doi.org/10.1590/01000683rbcs20151144

[36] Moraes, V.A. and Tauk-Tornisielo, S.M. (1997) Efeito da inoculação de Acetobacter diazotrophicus em cana-de-açúcar (Saccharum spp) variedade SP701143, a partir de cultura de meristemas. In: XIX Congresso Brasileiro de Microbiologia, SBM, Rio de Janeiro, 215.

[37] Verma, J.P., Yadav, J., Tiwari, K.N. and Kumar, A. (2013) Effect of Indigenous $\mathrm{Me-}$ sorhizobium spp. and Plant Growth Promoting Rhizobacteria on Yields and $\mathrm{Nu}$ trients Uptake of Chickpea (Cicer aritenium L.) under Sustainable Agriculture. Ecological Engineering, 51, 282-286. https://doi.org/10.1016/j.ecoleng.2012.12.022

[38] Saha, R., Saha, N., Donofrio, R.S. and Bestervelt, L.L. (2013) Microbial Siderophores: A Mini Review. Journal of Basic Microbiology, 53, 303-317. https://doi.org/10.1002/jobm.201100552

[39] Arencibia, A.D., Vinagre, F., Estevez, Y., Bernal, A., Perez, J., Cavalcanti, J., Santana, I. and Hemerly, A.S. (2006) Gluconacetobacter diazotrophicus Elicits a Sugarcane Defense Response against a Pathogenic Bacteria Xanthomonas albilineans. Plant Signaling \& Behavior, 1, 265-273. https://doi.org/10.4161/psb.1.5.3390

[40] Rosenblueth, M. and Martínez-Romero, E. (2006) Bacterial Endophytes and Their Interactions with Hosts. Molecular Plant Microbe Interactions, 19, 827-837. https://doi.org/10.1094/MPMI-19-0827

[41] Yasuda, M., Isawa, T., Shinozaki, S., Minamisawa, K. and Nakashita, H. (2009) Effects of Colonization of a Bacterial Endophyte, Azospirillum sp. B510, on Disease Resistance in Rice. Bioscience Biotechnology and Biochemistry, 73, 2595-2599. https://doi.org/10.1271/bbb.90402

[42] Oliveira, A.L.M., Canuto, E.L., Reis, V.M. and Baldani, J.I. (2003) Response of Micropropagated Sugarcane Varieties to Inoculation with Endophytic Diazotrophic Bacteria. Brazilian Journal of Microbiology, 34, 59-61. https://doi.org/10.1590/S1517-83822003000500020

[43] Suman, A., Gaur, A., Shrivastava, A.K. and Yadav, R.L. (2005) Improving Sugarcane Growth and Nutrient Uptake by Inoculating Gluconacetobacter diazotrophicus. 
Plant Growth Regulation, 47, 155-162. https://doi.org/10.1007/s10725-005-2847-9

[44] Reis, V., Lee, S. and Kennedy, C. (2007) Biological Nitrogen Fixation in Sugarcane. In: Emerich, C. and Newton W.E., Eds., Associative and Endophytic Nitrogen-Fixing Bacteria and Cyanobacterial Associations, Springer, Dordrecht, 213-232. https://doi.org/10.1007/1-4020-3546-2_10

[45] Carvalho, T.L.G., Ferreira, P.C.G. and Hemerly, A.S. (2011) Sugarcane Genetic Controls Involved in the Association with Beneficial Endophytic Nitrogen Fixing Bacteria. Tropical Plant Biology, 4, 31-41.

https://doi.org/10.1007/s12042-011-9069-2 